\title{
Long-term effects of cyclosporin A on cultured mouse pancreatic islets
}

\author{
A. Andersson, H. Borg, A. Hallberg, C. Hellerström, S. Sandler and A. Schnell \\ Department of Medical Cell Biology, Biomedicum, Uppsala University, Uppsala, Sweden
}

\begin{abstract}
Summary. In the light of recent attempts to treat newly-diagnosed Type 1 (insulin-dependent) diabetic patients with cyclosporin $\mathrm{A}$, and reports suggesting an impaired glucose tolerance following immunosuppresion therapy with cyclosporin $\mathrm{A}$, we investigated the long-term effects of cyclosporin $\mathrm{A}$ on islet $\beta$-cell morphology and function in vitro. Collagenase-isolated mouse pancreatic islets were cultured free-floating for 7 days in medium RPMI $1640+10 \%$ calf serum in the presence of cyclosporin $A(0.1$ or $1.0 \mathrm{mg} / \mathrm{l})$. Islets cultured in the presence of the higher cyclosporin A concentration had impaired islet proinsulin biosynthesis and insulin release when challenged with high glucose concentration. Moreover, the insulin content of the drug-exposed islets was decreased and so was the rate of DNA synthesis. The glucose
\end{abstract}

oxidation and respiratory rates, however, remained unaffected, suggesting that the impaired insulin production was not a result of defective oxidative metabolism. There were no changes in the ultrastructure or phospholipid biosynthesis of the islets after the drug treatment. These data indicate that cyclosporin A affects islets in culture, the clinical implications of which are so far difficult to assess. The inhibitory effect of cyclosporin A on islet cell DNA synthesis must nevertheless be considered in attempts to ameliorate Type 1 (insulin-dependent) diabetes, and when grafting islet cells in numbers primarily insufficient to cure the recipient.

Key words: Islet $\beta$ cell, cyclosporin $\mathrm{A}$, mouse.
Despite its liver and kidney toxicity cyclosporin A (CsA) has rapidly become the immunosuppressive agent most commonly used in clinical transplantation [1] including pancreatic transplantation [2]. CsA has also become an interesting therapeutical alternative for immune suppression therapy in Type 1 diabetes, since there is evidence that an autoimmune process directed at the insulin-producing $\beta$ cells may play a role in the development of this disease [3]. Indeed, CsA has been found to prevent the onset of insulin-dependent diabetes in BB Wistar rats [4]. On the other hand, it was recently reported that when switching four diabetic patients with combined cadaver kidney and pancreatic transplants from azathioprine-prednisolone to CsAprednisolone immunosuppressive therapy there was a deterioration in glucose metabolism [5]. Against this background, we investigated the possible adverse longterm effects of CsA on several aspects of pancreatic islet function by adding the drug, in the range of therapeutic concentrations, to media used for organ culture of pancreatic islets isolated from mice.

\section{Materials and methods}

\section{Islet preparation and culture}

Male, adult, non-inbred NMRI-mice (Anticimex, Sollentuna, Sweden) were used. Pancreatic islets, prepared by a collagenase method [6], were transferred in groups of approximately 100, not permitting cell attachment, to plastic Petri dishes (Sterilin, Teddington Middlesex, UK) containing $5 \mathrm{ml}$ tissue culture medium RPMI 1640 (glucose $11 \mathrm{mmol} / \mathrm{l}$ ) supplemented with $10 \%$ calf serum and antibiotics [7]. Cyclosporin A (1 mg, generously given by Sandoz, Täby, Sweden) was dissolved in absolute ethanol $0.1 \mathrm{ml}$, to which $0.02 \mathrm{ml}$ Tween 20 was added. Finally, medium RPMI 1640 was added dropwise to this solution to a final volume of $1 \mathrm{ml}$. Islets serving as controls were cultured in a medium supplemented with the appropriate solvents only. The medium was changed on days 3 and 5 of culture. Immediately before islet harvest at the end of the 7-day culture period, samples of the culture media were collected for radioimmunoassay of insulin [8].

\section{Islet viability tests}

Procedures for the incubation of the cultured islets in vitro have been described previously in detail: insulin release and content [7], proinsulin biosynthesis [7, 9] glucose oxidation and islet perifusion [10], oxygen uptake [11], phospholipid biosynthesis [12] and DNA synthe- 
Table 1. Long-term effects of cyclosporin $A$ on insulin production

\begin{tabular}{|c|c|c|c|}
\hline & Control islets & $\begin{array}{l}\text { Islets cultured } \\
\text { with } \mathrm{CsA}(0.1 \mathrm{mg} / \mathrm{l})\end{array}$ & $\begin{array}{l}\text { Islets cultured } \\
\text { with } \mathrm{CsA}(1 \mathrm{mg} / \mathrm{l})\end{array}$ \\
\hline Insulin accumulation (ng/dish) & $1845 \pm 180$ & $1475 \pm 180$ & $1580 \pm 300$ \\
\hline $\begin{array}{l}\text { Insulin release }(\mathrm{ng} / 60 \mathrm{~min} \text { per } 5 \text { islets }) \\
\text { Glucose }(1.67 \mathrm{mmol} / 1) \\
\text { Glucose }(16.7 \mathrm{mmol} / \mathrm{l})\end{array}$ & $\begin{array}{rr}1.2 \pm & 0.2 \\
21.7 \pm & 1.7\end{array}$ & $\begin{array}{rr}1.3 \pm & 0.2 \\
17.7 \pm & 1.8\end{array}$ & $\begin{aligned} 1.0 \pm & 0.2 \\
10.7 \pm & 1.2^{c}\end{aligned}$ \\
\hline Proinsulin biosynthesis as proportion of total protein biosynthesis $(\%)$ & $24.3 \pm \quad 1.7$ & $23.5 \pm 1.5$ & $18.6 \pm 1.2^{\mathrm{a}}$ \\
\hline
\end{tabular}

The islets were cultured for 1 week in RPMI 1640 supplemented with $10 \%$ calf serum and CsA.

CsA was not added to the short-term incubation media. Values are expressed as mean \pm SEM for six experiments.

${ }^{\mathrm{a}} p<0.05 ;{ }^{\mathrm{b}} p<0.01 ;{ }^{\mathrm{c}} p<0.001$ versus control islets

Table 2. Long-term effects of cyclosporin A on islet cell replication and glucose metabolism

\begin{tabular}{|c|c|c|}
\hline & Control islets & $\begin{array}{l}\text { Islets cultured } \\
\text { with CsA } 1 \mathrm{mg} / 1\end{array}$ \\
\hline $\begin{array}{l}\text { DNA synthesis } \\
\text { (dpm/ng DNA) }\end{array}$ & $5.0 \pm 0.4(12)$ & $3.9 \pm 0.3^{\mathrm{a}}(12)$ \\
\hline $\begin{array}{l}\text { Autoradiographic islet- } \\
\text { cell labelling index }(\%)\end{array}$ & $4.24 \pm 0.35(6)$ & $1.57 \pm 0.34^{b}(6)$ \\
\hline $\begin{array}{l}\text { DNA content } \\
\text { (ng/islet) }\end{array}$ & $20.2 \pm 1.0(12)$ & $23.2 \pm 1.2(12)$ \\
\hline $\begin{array}{l}\text { Glucose oxidation } \\
(16.7 \mathrm{mmol} / \mathrm{l}) \\
(\mathrm{pmol} / 120 \mathrm{~min} \text { per } 10 \text { islets })\end{array}$ & $708 \pm 36(6)$ & $631 \pm 33(6)$ \\
\hline $\begin{array}{l}\text { Respiration (nl/islet) } \\
\text { In glucose }(1.67 \mathrm{mmol} / \mathrm{l}) \\
\text { In glucose }(16.7 \mathrm{mmol} / \mathrm{l})\end{array}$ & $\begin{array}{r}6.6 \pm 0.6(5) \\
11.9 \pm 1.3(5)\end{array}$ & $\begin{array}{l}5.4 \pm 0.4(6) \\
8.8 \pm 0.8(6)\end{array}$ \\
\hline $\begin{array}{l}\text { Percentage respiratory } \\
\text { change }\end{array}$ & $75 \pm 11(6)$ & $64 \pm 12(6)$ \\
\hline $\begin{array}{l}\left.\text { D-(U- }{ }^{14} \mathrm{C}\right) \text { glucose incor- } \\
\text { poration }(16.7 \mathrm{mmol} / 1) \\
\text { (pmol glucose } / 120 \mathrm{~min} \text { per } \\
25 \text { islets) into: }\end{array}$ & & \\
\hline Phosphatidylinositol & $1.89 \pm 0.15(13)$ & $1.86 \pm 0.23(12)$ \\
\hline Phosphatidylserine & $1.34 \pm 0.24(13)$ & $1.07 \pm 0.19(12)$ \\
\hline Phosphatidylcholine & $9.41 \pm 0.56(13)$ & $9.94 \pm 1.17(12)$ \\
\hline $\begin{array}{l}\text { Phosphatidylethanol- } \\
\text { amine + phosphatidyl- } \\
\text { glycerol }\end{array}$ & $3.58 \pm 0.23(13)$ & $3.52 \pm 0.42(12)$ \\
\hline
\end{tabular}

The islets were cultured for one week in RPMI 1640 supplemented with $10 \%$ calf serum and CsA. CsA was not added to the short-term incubation media. Values are expressed as mean \pm SEM with number of experiments within parentheses. ${ }^{a} p<0.05$ and ${ }^{b} p<0.001$ versus control islets

\section{Results}

\section{Insulin production}

Culture of islets for 1 week in the presence of CsA $/ 1(0.1$ or $1 \mathrm{mg}$ ) produced a slight reduction of the islet insulin content, whereas no effects of the drug were observed on the accumulation of insulin in the culture medium (Table 1). When challenged with high glucose concentration in the subsequent short-term incubations, the islets exposed to the higher CsA concentration secreted less insulin than the control islets (Table 1). They were, however, still responding to high glucose with a tenfold increase of insulin secretion. In perifusion experiments islets cultured in the presence of CsA $(1 \mathrm{mg} / 1)$ showed a marked attenuation of both the first peak and the second, lower phase of insulin release when stimulated with high glucose $(16.7 \mathrm{mmol} / 1)$ (data not shown).

Glucose-stimulated proinsulin biosynthesis of islets exposed to CsA $(1 \mathrm{mg} / \mathrm{l})$ was reduced to $<50 \%$ that of the controls (Table 1). A significant but less pronounced impairment of total protein biosynthesis led to a decrease in the percentage of radioactivity incorporated into proinsulin in relation to the totally incorporated radioactivity (Table 1 ).

\section{Islet cell DNA synthesis}

There was a slight reduction in the rate of DNA synthesis in islets exposed for 1 week to CsA $(1 \mathrm{mg} / \mathrm{l})$ as shown by the incorporation of ${ }^{3} \mathrm{H}$-thymidine into islet DNA (Table 2). Likewise, the labelling index of the CsA-exposed islet cells was significantly decreased. This impairment, however, did not affect the islet content of DNA (Table 2).

\section{Glucose metabolism}

has recently been described [14]. In the present experiments the concentration of ${ }^{3} \mathrm{H}$-thymidine added to the culture medium was $1 \mathrm{mCi} / 1$ and the labelling period was extended to $16 \mathrm{~h}$. Details of the preparation of the electron micrographs were published recently [15].
No long-term metabolic effects of the drug on the oxidative islet metabolism were recorded in the glucose 
oxidation and oxygen uptake experiments (Table 2). Thus, exposure of islets for one week to CsA $(1 \mathrm{mg} / 1)$ did not affect the subsequent production of ${ }^{14} \mathrm{CO}_{2}$ from $\mathrm{D}-\left(\mathrm{U}-{ }^{14} \mathrm{C}\right)$ glucose during a 2-h incubation period. Neither did the drug exposure influence the increase in respiratory rate when the islets were challenged with high glucose concentration in Cartesian divers. Finally, no effects were observed on the incorporation of ${ }^{14} \mathrm{C}$-glucose into the different phospholipid classes of islets exposed to CsA for one week (Table 2).

\section{Islet cell ultrastructure}

Ultrastructural studies of the CsA-exposed islet cells showed no signs of nuclear pycnosis. The mitochondria and endoplasmic reticulum were not affected. The $\beta$ cells were well granulated and, as in the controls, lysosomal structures were frequently observed.

\section{Discussion}

Knowledge about the mechanism of action of CsA still remains incomplete, although it has been suggested that this drug interferes with the process of primary lymphocyte activation [16]. Even less is known about the mechanisms behind the toxic effects of CsA on kidney and liver cell function. From a clinical point of view, it has been found that these side effects are reversible and dose-dependent. The impairment of glucose tolerance reported by Gunnarsson et al. [5] following a change in immunosuppressive treatment from azathioprine to CsA in four kidney-plus-pancreas-grafted patients were attributed to an increased insulin resistance, perhaps following an increased circulating glucocorticoid concentration. It should be noted that in another study treatment with CsA did not lead to a deterioration in endocrine function of the grafted pancreas [17]. It was furthermore shown that CsA failed to affect $\beta$ cell function in acute experiments in vitro [18]

The findings of the present study nevertheless suggest that prolonged exposure to CsA impairs islet $\beta$ cell function, although the present drug concentration $(1 \mathrm{mg} / \mathrm{l})$ somewhat exceeds that measured in the blood of CsA-treated patients. It seems as if this chronic deterioration is not effected via an influence either on the oxidative metabolism of the islets, or on the phospholipid metabolism. The detrimental effect of CsA appears to be located at the level of protein biosynthesis. This could lead to a reduced insulin content of the CsAexposed islets, which may well explain the impairment of glucose-stimulated insulin release. An influence of CsA on the glucose recognition system of $\beta$ cells cannot, however, be excluded.

The present finding that CsA reduces the rate of DNA synthesis in cultured islets is perhaps not surprising, since the biologically unique activity of this drug is the immunosuppressive effect mediated through block- ing of the precursor $T$ cell in $G_{0}$ or early $G_{1}$ phase of the cell cycle [16]. It may be speculated that the active mitogen in the present islet culture experiments is glucose $(11 \mathrm{mmol} / \mathrm{l})$, the stimulatory effect of which is inhibited by CsA. It is intriguing that corticosteroids, which are often used in combination with CsA in immunosuppressive therapy, have been likewise found to inhibit islet-cell replication in vitro [19]. It should be mentioned in this context that in none of these studies has a preferential effect on any of the different cell types of the islets been documented. There is however ample evidence to suggest that $\beta$ cells are actively dividing in these preparations $[13,14]$.

Great caution must be exercised when transferring the present data obtained in vitro to the clinical situation. The present observation of inhibition of DNA synthesis by CsA should nevertheless be considered in the current attempts to ameliorate early Type 1 diabetes [20]. Likewise, this effect of CsA could be deleterious when grafting islet cells into diabetics patients [21], since the long-term success of such treatment may depend not only on immune reactions but also on the replicatory activity in the islet graft.

Acknowledgements. We are grateful to K.Flink, E. Forsbeck, I.-B.Hallgren, A. Nordin and P. Wentzel for excellent technical assistance and to A. Snellman for preparation of the manuscript. Financial support from the Swedish Medical Research Council (12x-109; $12 \mathrm{x}-6538$ ), the Swedish Diabetes Association, the Kroc Foundation and the Nordic Insulin Fund is gratefully acknowledged.

\section{References}

1. Merion RM, White DJG, Thiru S, Evans DB, Calne RY (1984) Cyclosporin: five years experience in cadaveric renal transplantation. N Engl J Med 310: 148-154

2. Rynaziewicz JJ, Sutherland DER, Ferguson RM, Squifflet JP, Morrow CE, Goetz FC, Najarian JS (1982) Cyclosporin A for immunosuppression: observations in rat heart, pancreas, and islet allograft models and human renal and pancreas transplantation. Diabetes 31 (suppl 4): 92-108

3. Nerup J, Lernmark Å (1981) Autoimmunity in insulin-dependent diabetes. Am J Med 70: 135-141

4. Laupacis A, Gardell C, Dupre J, Stiller CR, Keown P, Wallace AC, Thibert $P(1983)$ Cyclosporin prevents diabetes in $B B$ Wistar rats. Lancet $1: 10-12$

5. Gunnarsson R, Klintmalm G, Lundgren G, Wilczek H, Östman J, Groth CG (1983) Deterioration in glucose metabolism in pancreatic transplant recipients. Lancet 2: 571-572

6. Howell SL, Taylor KW (1968) Potassium ions and the secretion of insulin by islets of Langerhans incubated in vitro. Biochem $\mathrm{J} 108$ : $17-24$

7. Andersson A (1978) Isolated mouse pancreatic islets in culture: effects of serum and different culture media on the insulin production of the islets. Diabetologia 14: 397-404

8. Heding LG (1972) Determination of total serum insulin in insulintreated patients. Diabetologia 8: 260-266

9. Berne C (1975) Anti-insulin serum coupled to Sepharose 4B as a tool for the investigation of insulin biosynthesis in the B-cells of obese hyperglycemic mice. Endocrinology 97: 1241-1247

10. Andersson A, Sandler S (1983) Viability tests of cryopreserved endocrine pancreatic cells. Cryobiology 20:161-168

11. Hellerström C (1967) Effects of carbohydrates on the oxygen con- 
sumption of isolated pancreatic islets of mice. Endocrinology 81 : 105-112

12. Hallberg A, Berne C, Andersson A (1984) Effects of chloroquine on lipid metabolism of mouse pancreatic islets. Biochem Pharmacol (in press)

13. Swenne I, Bone AJ, Howell SL, Hellerström C (1980) Effects of glucose and amino acids on the biosynthesis of DNA and insulin in fetal rat islets maintained in tissue culture. Diabetes 29: 686-692

14. Swenne I (1982) The role of glucose in the in vitro regulation of cell cycle kinetics and proliferation of fetal pancreatic B-cells. Diabetes 31: 754-760

15. Borg LAH, Andersson A (1981) Long-term effects of glibenclamide on the insulin production, oxidative metabolism and quantitative ultrastructure of mouse pancreatic islets maintained in tissue culture at different glucose concentrations. Acta Diabetol Lat 18: $65-83$

16. Borel JF, Lafferty KJ (1983) Cyclosporin: speculation about its mechanism of action. Transplant Proc 15: 1881-1885

17. Pozza G, Traeger J, Dubernard JM, Sechi A, Bosi E, Pontiroli A (1983) Cyclosporin and glucose tolerance in pancreas allotransplantation. Lancet 2: 1080
18. Andersson A, Sandler S (1984) Culture and cryopreservation of isolated pancreatic islets. In: Andreani D, DiMario U, Federlin KF, Heding LG (eds) Immunology of diabetes. Kimpton Teviot Publications, London, pp 177-186

19. Andersson A (1975) Synthesis of DNA in isolated pancreatic islets maintained in tissue culture. Endocrinology 96: 1051-1054

20. Stiller CR, Laupacis A, Dupre J, Jenner MR, Known PA, Rodger PA, Wolff BMJ (1983) Cyclosporine for treatment of early Type I diabetes: preliminary results. N Engl J Med 308: 1226-1227

21. Groth CG, Andersson A, Björkén C, Gunnarsson R, Hellerström C, Lundgren G, Petersson B, Swenne I, Östman J (1980) Transplantation of fetal pancreatic microfragments via the portal vein to a diabetic patient. Diabetes 29 (Suppl 1): 80-83

Dr. A. Andersson

Department of Medical Cell Biology

PO Box 571

S-75123 Uppsala

Sweden 